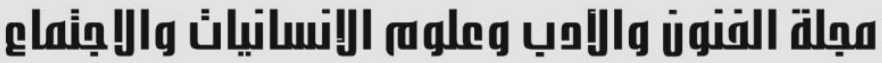 \\ Journal of Arts, Literature, Humanities and Social Sciences www.jalhss.com \\ Volume (54) July 2020 \\ العدد (54) يوليو 2020
}

\section{The Provenance and Origins of Arabic Calligraphy as an Islamic Art}

\author{
Dr. Mojib Alzahrani \\ Art Education Department - Faculty of Education \\ King Saud University - Saudi Arabia \\ Email: mojalzahrani@ksu.edu.sa
}

\begin{abstract}
Arabic calligraphy constitutes one of the most prominent and inveterate areas of Islamic art. The study aims to find out the provenance of Arabic Calligraphy and answer the question about what is the origin of Arabic calligraphy? In truth, answering this question is not easy, predominantly because there have been so many diverging opinions. Given its deep and ancient roots, question of its origin is critical. This study attempts to answer this question by examining four major theories regarding the origin of Arabic writing and calligraphy: the theory of restriction and inspiration, the Persian theory, the Musnad theory, and the Nabataean theory. These four theories are reviewed, compared, and analyzed. The results of the study confirm that the origin of Arabic calligraphy derives to a large extent from Nabataean calligraphy and to a much lesser extent from Musnad calligraphy. An additional influence on the appearance and morphology of Arabic calligraphy is Persian Pahlavi calligraphy. The most recent archeological discovery made in Saudi Arabia was an archeological inscription found in a deserted area of Wadi Tharouq, in Daws in AlMandaq Province supports this trend. The Saudi Commission for Tourism and National Heritage announced that this stone inscription dates back to the seventh century AD. It is a passage from the Quran. Analysis reveals the similarity between the script of this inscription and Nabatean calligraphy in terms of the composition of the words and the character forms.
\end{abstract}

Keywords: Arabic calligraphy, Nabataean writing, Persian writing, Musnad calligraphy, theory of restriction and inspiration. 


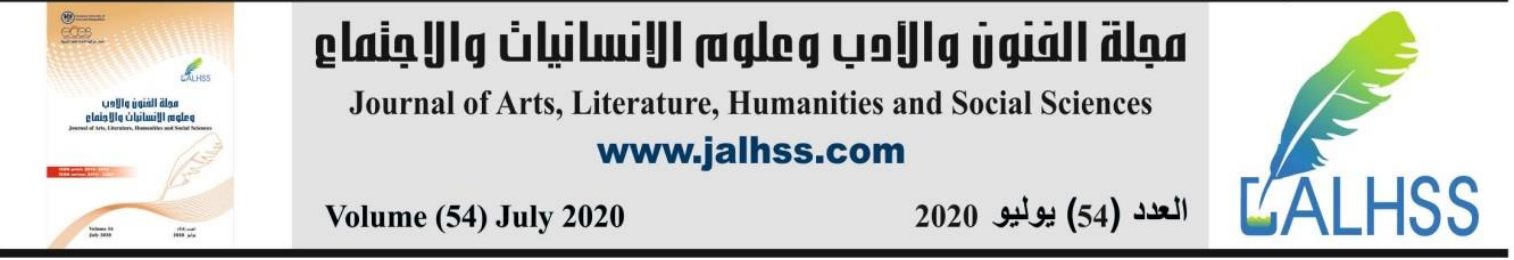

\section{INTRODUCTION}

Writing is undoubtedly one of the most important human inventions in history (Diamond, 2005), in that it has transformed human civilization from primitive oral traditions to the documentation of human life. In addition, writing has led to the development of various domains of knowledge, the solid pillars upon which both ancient and contemporary civilizations have developed and spread.

Islamic civilization is considered one of the human civilizations that cultivated reading and writing, leading to the evolution of Arabic writing from a practical to a fine art. Islamic art, one of the highest accomplishments of human civilization, includes calligraphy among its forms. Calligraphy emerged as an independent art during the Umayyad Caliphate (Rabi, Amrouch, \& Mahani, 2018). Recently, Arabic calligraphy has become one of the most prominent forms of Islamic art, occupying an esteemed international status. This status has attracted the attention and interest of specialists and scholars to its beauty and wonders, which transcend mere writing and delve into philosophical concerns. Indeed, a close observer of the development of Arabic calligraphy will discover a tremendous evolution, especially in its aesthetic and morphological dimensions. From its origins in disjointed letters that served the task of communication, it has blossomed into an art rich in content and beauty, as illustrated in Figure 1.

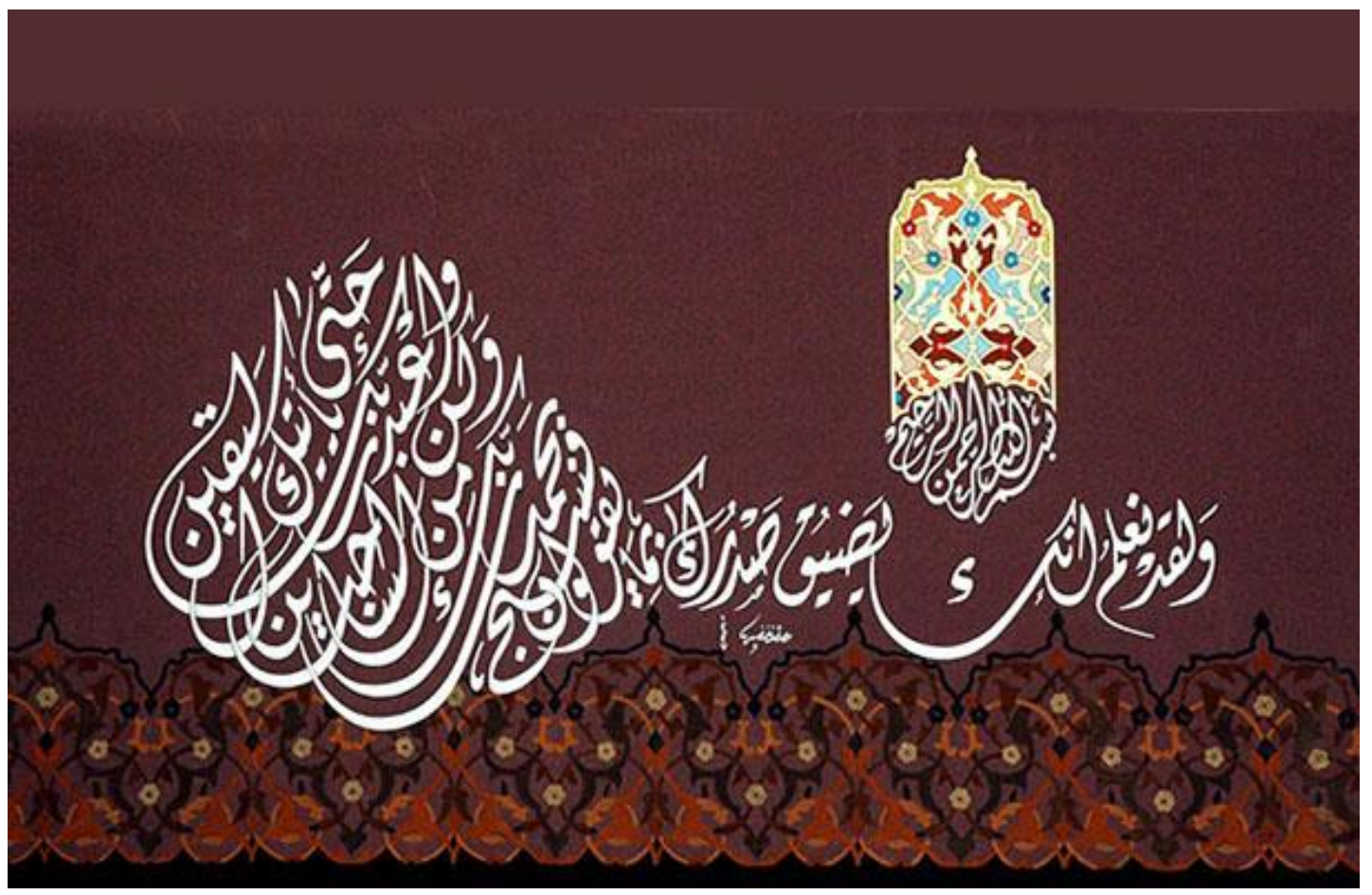

Figure 1 . The beauty and elegance of Arabic calligraphy makes it an outstanding art. 


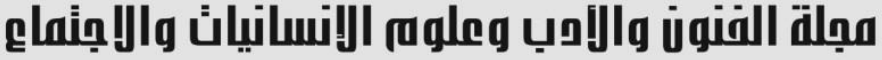 \\ Journal of Arts, Literature, Humanities and Social Sciences www.jalhss.com \\ Volume (54) July 2020 \\ العدد (54) يوليو 2020}

The main reason, besides its being so widespread, for the many current studies on the forms, aesthetics, and philosophy of Arabic calligraphy is the great evolution that it has undergone. Today, up to twenty-five percent of the world population uses Arabic script and calligraphy in their writing, in languages such as Arabic, Urdu, Sindhi, Pashto, and Persian (Razzak \& Mirza, 2011). Emerging as a disordered system of letters in 620 A.D., by 760 calligraphy developed into a jubilant art as it became an important decorative art used to adorn buildings, mosques, books, and carpets (Rania \& Alotaibi, 2018). This evolution, as the necessary anchor for research, leads to a logical question about the origin of calligraphy and its early roots, as calligraphy has a linguistic component and the art and writing system are both derived from a common source.

However, it should be recognized that the origin of Arabic calligraphy is directly connected to the origin of Arabic writing, and investigating this origin has many inherent difficulties, which authors have stressed. Mousa (2001) stated that the origin of Arabic writing is considered an uncertain matter among specialists. Allen (2000) also mentioned that earnest studies of the provenance of Arabic writing still require much effort, a possible explanation for the complications involved in determining the origin of Arabic calligraphy.

In fact, the author discovered this complication when he was assigned to teach a course on Islamic arts to PhD students. Part of the course covered Arabic calligraphy. Subsequently, when the author reviewed studies that covered the provenance of Arabic calligraphy, he found that they differed noticeably in their determination of the origin of Arabic writing. Thereafter, the author determined to investigate this issue and conduct research to learn the truth of the origin of Arabic calligraphy and its early development

What then is the origin of Arabic calligraphy? In truth, answering this question is not easy, predominantly because there have been so many diverging opinions and attempts to answer it, especially ancient speculations that lack concrete evidence. Therefore, Mousa's statement above, which affirms that the determining the origin of Arabic calligraphy is highly uncertain even among specialists, is utmost importance. This difficulty became more vivid as the author began investigating.

Each opinion claims to be the true and most faithful account, providing proofs to back its claims. Though many such claims have no concrete evidence, as will be seen. Thus, these opinions remain an exercise of conjecture. More scientific research is needed to base the most accurate of these opinions on concrete and documented evidence. Interestingly, this variety of opinions has not impacted the larger evolution of Arabic calligraphy as a fine art.

The author focused on the most common and prominent opinions. This limited the scope of the research to four major theories that trace Arabic calligraphy to its 


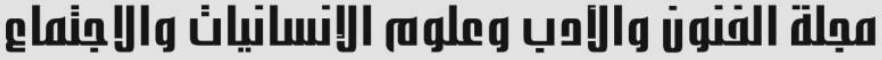 \\ Journal of Arts, Literature, Humanities and Social Sciences www.jalhss.com \\ Volume (54) July 2020 \\ العدد (54) يوليو 2020}

source. The term "theory" is used instead of "opinion," even though the latter is often used by the supporters of these theories in studies. These theories will be presented, discussed, analyzed, and compared. They can be summarized as follows:

- The restriction and inspiration theory

- The Persian theory

- The Musnad theory

- The Nabataean theory

\section{The Restriction and Inspiration Theory}

Starting in the seventh century A.D., there was a widespread tendency among Arab authors to view the origin of Arabic writing and calligraphy as inspired by God (Allah): it had been taught to Adam by God, and Ismail transmitted it in turn to the Arabs (Ibrahim, 2014). Advocates of this theory support their stance with religious and historical texts, demonstrating that their view is based on the interpretations of ancient scholars. These early interpretations claim that Arabic writing was transmitted throughout history until it reached its current form. Among the texts used as evidence, we find a passage from the Quran: "In the name of Allah, the merciful 'He taught Adam the names - all of them'." (The Noble Quran, 2013, 6). This passage has been interpreted to signify that Adam was taught to write these names (Mahdi, 2014). This is the theory of Ibn Fares (941-1004), one of its earliest proponents. This theory relies on a variety of religious texts, such as: "Nun, by the pen and record with which men write" and "He who taught the use of the pen, taught man that which he knew not." (The Noble Quran, 2013, 564) The "pen" in these verses is taken to indicate the existence of Arabic writing at that time.

Historical texts are also provided as proof for the validity of this theory. Around the 660 A.D., Ka'b al-Ahbar wrote that the first person to write in Hebrew, Syrian, and Arabic was Adam. Three hundred years before he died, Adam wrote books on clay tablets, which he then burned, turning the tablets into ceramic. Some of these books survived the Flood in the time of Noah, including the Arabic book, which was handed down through generations until Abraham gave it to Ismail (Omran, 2009,).

Another source of evidence for the theory are some of the sayings of the prophet from the Hadith narrated by Abu Dharr al-Ghifari (618-652 A.D.):

I asked the prophet Mohamed, peace be upon him, "Oh messenger of Allah, what is every prophet sent with?" The prophet answered: "With a book from God." And I said: "Oh messenger of Allah, what was the book sent with Adam?" He said: A-B-TTH-J [ أ , l the recitation of the Arabic alphabet]. Then, I said: "Messenger of Allah, how many letters are there?" He answered: "Twenty-nine letters." (Ibrahim, 2014) 


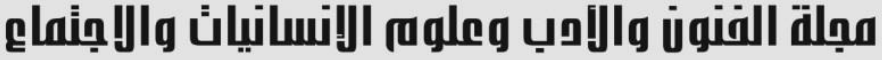 \\ Journal of Arts, Literature, Humanities and Social Sciences www.jalhss.com \\ Volume (54) July 2020 \\ العدد (54) يوليو 2020}

In fact, this theory_ — which its supporters present as a history of Arabic writing and thus the origin of Arabic calligraphy - cannot stand up to scientific fact and logic. The theory and its concepts are based either on a misinterpretation of the Holy Quran, on incorrect prophetic sayings, or historical narratives that cannot pass muster as scientifically based evidence. Therefore, there should be no complication in replying to these opinions and conjectures, which claim that Arabic calligraphy was inspired by God. Concerning the first verse cited from the Quran ("And he taught Adam the names - all of them."), it actually only indicates that Adam learned the names of the creatures around him and does not, in any sense, mean he learned to write in Arabic. The other verses cited from the Quran ("Nun, by the pen ..." and "He who taught the use of the pen ...") do not contain any plain evidence of or allusion to the writing mentioned being Arabic. That it is Arabic is merely assumed, and thus the misinterpretation of these verses has no concrete or religious proof.

As for the passages from the Hadith, the author did not find that either provided proper proof of the origin of Arabic writing, besides the fact that the sayings have not been proven to have been spoken by the prophet Mohamed, peace be upon him. In fact, the author could not find any indication of the origin or source of Arabic writing in the six authentic and reliable books of the prophet's sayings for as narrated by Abu Dharr al-Ghifari. As regards the narration of Ka'b al-Ahbar, which claims to be a record of the companions of the prophet, the author discovered that specialists on the prophet's sayings do not consider any of these sayings to have come from the prophet, and so they are unreliable as evidence.

Consequently, based on the above findings, the theory of restriction and inspiration is ineligible as it lacks the basic scientific support for its claims about the origin of Arabic calligraphy.

\section{The Persian Theory}

There is a more recent trend that claims to find the origins of Arabic calligraphy in Persian calligraphy. Abulhab (2007) stresses that the origins of Arabic calligraphy derive from the sophisticated writing used in Persia and Mesopotamia in the early centuries of the common era. There is a resemblance between Persian and Arabic calligraphy. Abulhab particularly references the claims of of Ibn al-Nadim, who believed that Arabic Aljazm calligraphy was derived from the ancient Persian calligraphy. Lafi (2015) also claims that Persian Pahlavi calligraphy had a prominent influence on Arabic writing. At that time, calligraphy was widespread and prospered in Persia and in Arab countries under Persian rule, especially during the Sasanian period. Lafi claims this is evidence that Persian writing is the basis of Arabic calligraphy. However, after examining the evidence for these theories, the claims seem imprecise and, especially when compared, to not provide sufficient proof. The theory as a whole must be rejected. 


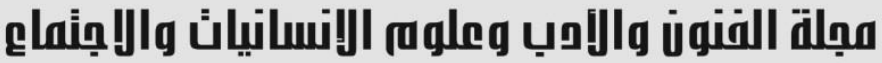 \\ Journal of Arts, Literature, Humanities and Social Sciences www.jalhss.com \\ Volume (54) July 2020 \\ العدد (54) يوليو 2020}

Ibn al-Nadim may have been the first to claim that Arabic calligraphy is derived from ancient Persian calligraphy (Abulhab, 2007). Ibn al-Nadim was a man of letters who lived in Baghdad between 1000 and 1049 A.D., during the time when Arabic calligraphy expanded into Persia (this will be clarified below). The primary concern with Ibn al-Nadim's claim is that he may have confused Persian for Nabataean calligraphy. This is likely as there is no outward resemblance between Persian and Arabic scripts. Ancient Persian is in the Indo-European family of languages, whereas Arabic is Afro-Asiatic (Bishop, 1998). Furthermore, the history of Persian writing does not support the claims of Ibn al-Nadim nor Arabic calligraphy's Persian origins.

Baluch (2006) describes Persian calligraphy in three major periods: ancient Persian (551-331 B.C.), when cuneiform was used; middle Persian (331 B.C.- 800 A.D.), during which Pahlavi was used in the Sasanian Empire; and modern Persian (800 A.D.-present), in which Arabic letters are used. A comparison of Arabic and ancient Persian scripts reveals no resemblance between the two (Fig. 2).

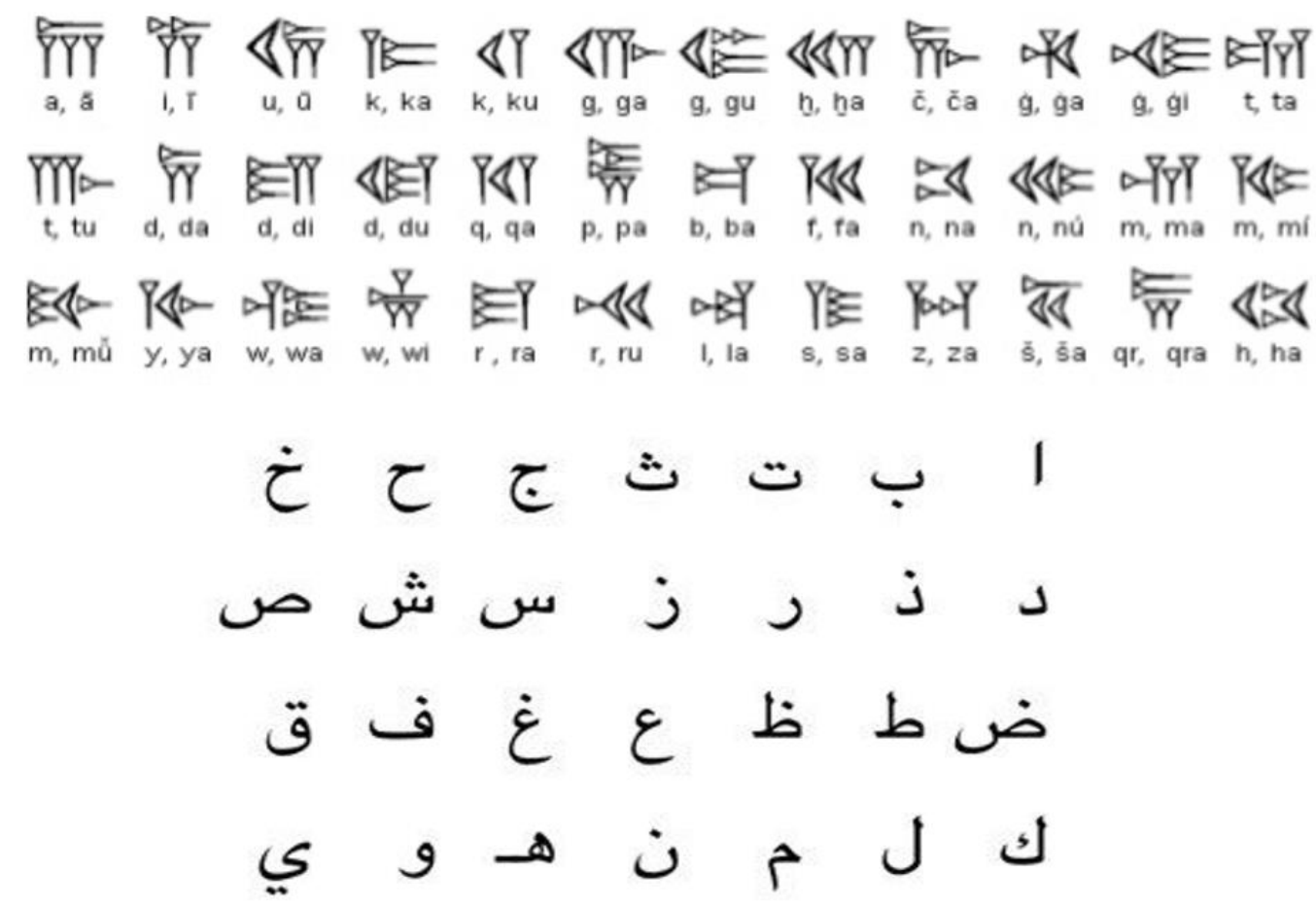

Figure 2. Comparison of Arabic and ancient Persian scripts

In middle Persian (Pahlavi), there is some resemblance to Arabic. This resemblance is most noticeable when the letters are joined, but the resemblance is no longer clear when the individual letters are compared side by side (Fig. 3). 


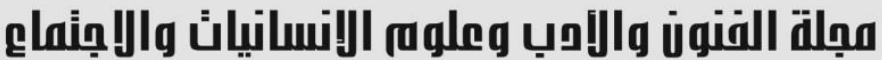

Journal of Arts, Literature, Humanities and Social Sciences

www.jalhss.com

\begin{tabular}{|c|c|c|c|}
\hline Pahlavi & Arabic & Pahlavi & Arabic \\
\hline & 1 & 4 & " \\
\hline لـ & 21 & $\downarrow$ & $\dot{~} \dot{\varepsilon} \dot{\varepsilon}$ \\
\hline J & ب ب & 2 & J \\
\hline$\Sigma$ & ए १े & $n$ & ث صس \\
\hline 3 & د & 21 & ش ش \\
\hline & - & 2 & ت ط \\
\hline & e & 2 & و \\
\hline 2 & $s$ & & 9 \\
\hline r & $\tau \Delta$ & & و \\
\hline & " & $\Omega$ & $\dot{\tau}$ \\
\hline$\Sigma$ & ج ج & 2 & ى ثي \\
\hline 3 & $\checkmark$ & & ظ ض ن ز \\
\hline 3 & J & - & j \\
\hline to & مـ م & & | \\
\hline$L$ & ن ن & & \\
\hline & - & & \\
\hline
\end{tabular}

Figure 3. Comparison of Pahlavi and Arabic scripts

With such clear visual evidence, the author views this theory as unconvincing even though Arabic calligraphy was influenced by Pahlavi calligraphy in the joining and interlacing of letters. If one excludes this element, the resemblance fades. Moreover, resemblance, on its own, does not demonstrate that Persian calligraphy is the origin of Arabic calligraphy. Such an influence is likely between two cultures that have been neighbors for hundreds or even thousands of years. Persian calligraphy's influence was on the general appearance of writing but not on the shape of the letters. In fact, it may be more appropriate to claim that Arabic influenced Persian writing, 


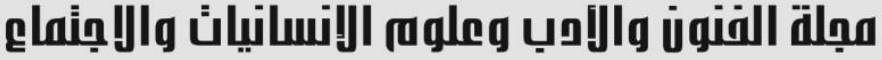 \\ Journal of Arts, Literature, Humanities and Social Sciences www.jalhss.com \\ Volume (54) July 2020 \\ العدد (54) يوليو 2020}

as Persians adopted Arabic writing to the Persian spoken language, the practice from 800 A.D. on.

\section{The Musnad Theory}

Advocates of this theory claim that Musnad calligraphy is the origin of Arabic calligraphy. Musnad was located in the southern part of the Arabian peninsula, an area from which the Sabaean civilization spread into Yemen (Mahdi, 2014). Musnad calligraphy appeared in Yemen and the Horn of Africa in the ninth century B.C. It is consists of twenty-nine letters and is read right to left for individual/odd lines and left to right for parity lines (Showman, 2001). The majority of Arab scholars, whether ancient or modern, ascribe to this theory. They attribute Arabic calligraphy to Musnad writing, which was popular in the southern part of the Arabian peninsula during the time of the Sabaean and Himyarite Kingdoms.

Ibn Jinni (941-1002) and Fairuzabadi (1329-1415) were among the ancient scholars who adopted this theory (Ibrahim, 2014). Ibn Khaldoun (1332-1406) claimed that as Musnad calligraphy achieved a high degree of precision and originality, it migrated from Yemen to Mecca and Taif in the west and then to Al-Hirah in Iraq, during the rule of the Arab Lakhmids (Showman, 2001). Of the modern scholars who have adopted this theory, Ahmed Sharafuddin claims that Musnad calligraphy is the origin of Arabic calligraphy in the southern and northern regions of the Arabian peninsula around the second century A.D. and that Arabic calligraphy was influenced by Phoenician and Aramaic (Mahdi, 2014).

Ibrahim (2014) presented various proofs of the Musnad theory:

1) Arabic calligraphy came to Al-Hijaz (Saudi Arabia) through Khalfajan, the writer of God's revelation to the prophet Hud who was sent to Al-Ahqaf in Yemen (Ibrahim, 2014).

2) The Saba-Yemeni civilization influenced the whole Arabian peninsula, imposing its form of writing on every area under its rule.

3) Yemeni Thamoudian inscriptions prove the resemblance between Musnad and Arabic calligraphy.

4) Fourteen of the letters in the Musnad and Arabic alphabets resemble each other.

Despite this theory's notability and the support it receives from many scholars, including Ibn Khaldoun, the author believes its claims have been exaggerated. An examination of evidence offered as well as a comparison of Arabic and Musnad calligraphy are necessary.

As regards the evidence adduced by advocates of this theory, some is weighty and some is lacking. One example of the latter kind of evidence, (1) above, is the claim that Khalfajan, the writer of God's revelation to Hud, brought Musnad calligraphy to Yemen and Hejaz. This claim is unreliable. The prophet Hud was one of Noah's grandsons, and there is no proof that he was acquainted with Musnad calligraphy. 


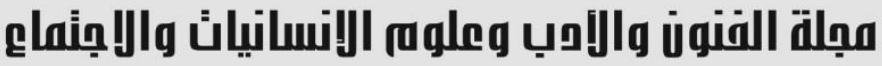 \\ Journal of Arts, Literature, Humanities and Social Sciences www.jalhss.com \\ Volume (54) July 2020 \\ العدد (54) يوليو 2020}

According to Deborah Coulter-Harris (2013), Musnad only dates to as early as 1000 B.C., whereas the story of the prophet Hud dates to around 2500 B.C., leaving no room for overlap. In addition, there is some controversy surrounding whether the story of Hud took pace in Yemen, Sham (the modern-day Levant), or Iraq, as there are contradictory claims made about the location of his grave. Some claim it is in Hadhramaut, others in Damascus, and still others in Karbala.

The second proof, that the Kingdom of Saba spread across the Arabian peninsula and imposed its language, culture, and especially its style of calligraphy on its territories, is logical and, notably, is supported by monuments discovered in the central region of the Arabian peninsula dating to the fifth century B.C. Nevertheless, the Kingdom of Saba, which was founded around 1000 B.C., was overthrown by another kingdom and many more ruled the Arabian peninsula, or parts of it, thereafter. One possible implication of this fact is that these kingdoms might have tried to destroy or erase any manifestations of Saba civilization or replaced them with ones that suited them. The Kingdom of Dilmun, which used Sumerian calligraphy, was one such kingdom that dominated parts of the eastern region of the Arabian peninsula (Baglawa, 2016). The Kingdom of Kindah, founded in 547 B.C. at the center of the Arabian peninsula, used Musnad calligraphy, as is proven by artifacts found in the Alfaw district. These artifacts are the historically youngest evidence of Musnad calligraphy on the Arabian peninsula.

The third proof concerns Thamoudian inscriptions that purport to demonstrate the resemblance of Musnad calligraphy to Arabic calligraphy. The author has compared the Thamoudian inscriptions to Arabic calligraphy and script and finds no resemblance (Fig. 4. The author also considered the fourth proof, that fourteen of the letters in the Musnad and Arabic alphabet resemble each other, but found that only

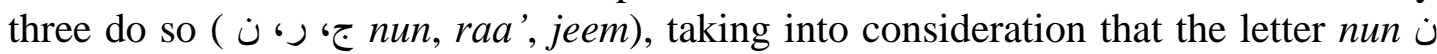
can be written in more than one way in Arabic calligraphy (Fig. 5). 


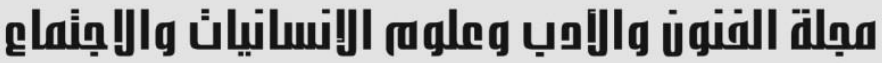

Journal of Arts, Literature, Humanities and Social Sciences www.jalhss.com

\begin{tabular}{|c|c|}
\hline 向只为 & 6 \\
\hline$\cup \frown נ$ & $u$ \\
\hline$\wedge \wedge \circ$ & e \\
\hline$f+d a \Omega$ & 2 \\
\hline$\gamma \wedge \Psi \wedge \psi \phi$ & $\rightarrow$ \\
\hline$\oplus \theta \theta 凹 \square \square \otimes \boxplus \odot$ & g \\
\hline 17 & ; \\
\hline n $n \Rightarrow \exists \Rightarrow \Psi \quad \psi \psi \psi$ & $\varepsilon$ \\
\hline 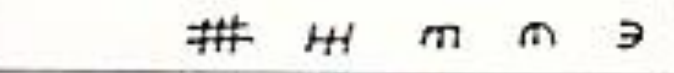 & $b$ \\
\hline $9 \quad 6 \quad 4$ & ي \\
\hline 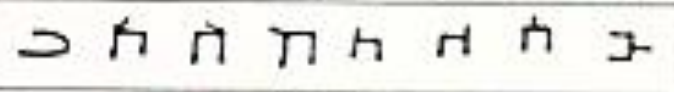 & $\stackrel{4}{-1}$ \\
\hline 7$) \csc 7 \lambda+1$ & J \\
\hline 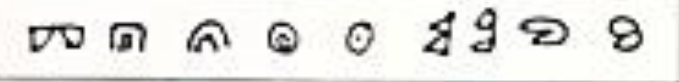 & 阝 \\
\hline $4532\{1$, & 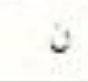 \\
\hline 内七コ & $\sim$ \\
\hline$\therefore \quad \therefore \quad 0$ & $\varepsilon$ \\
\hline$\sim\{\sim 3 \varepsilon m$ & 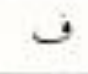 \\
\hline
\end{tabular}

Figure 4. Comparison of Thamoudian inscription and Arabic script 


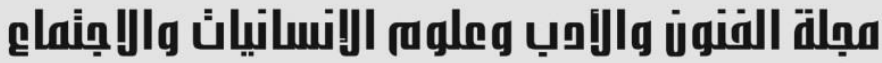

Journal of Arts, Literature, Humanities and Social Sciences

www.jalhss.com

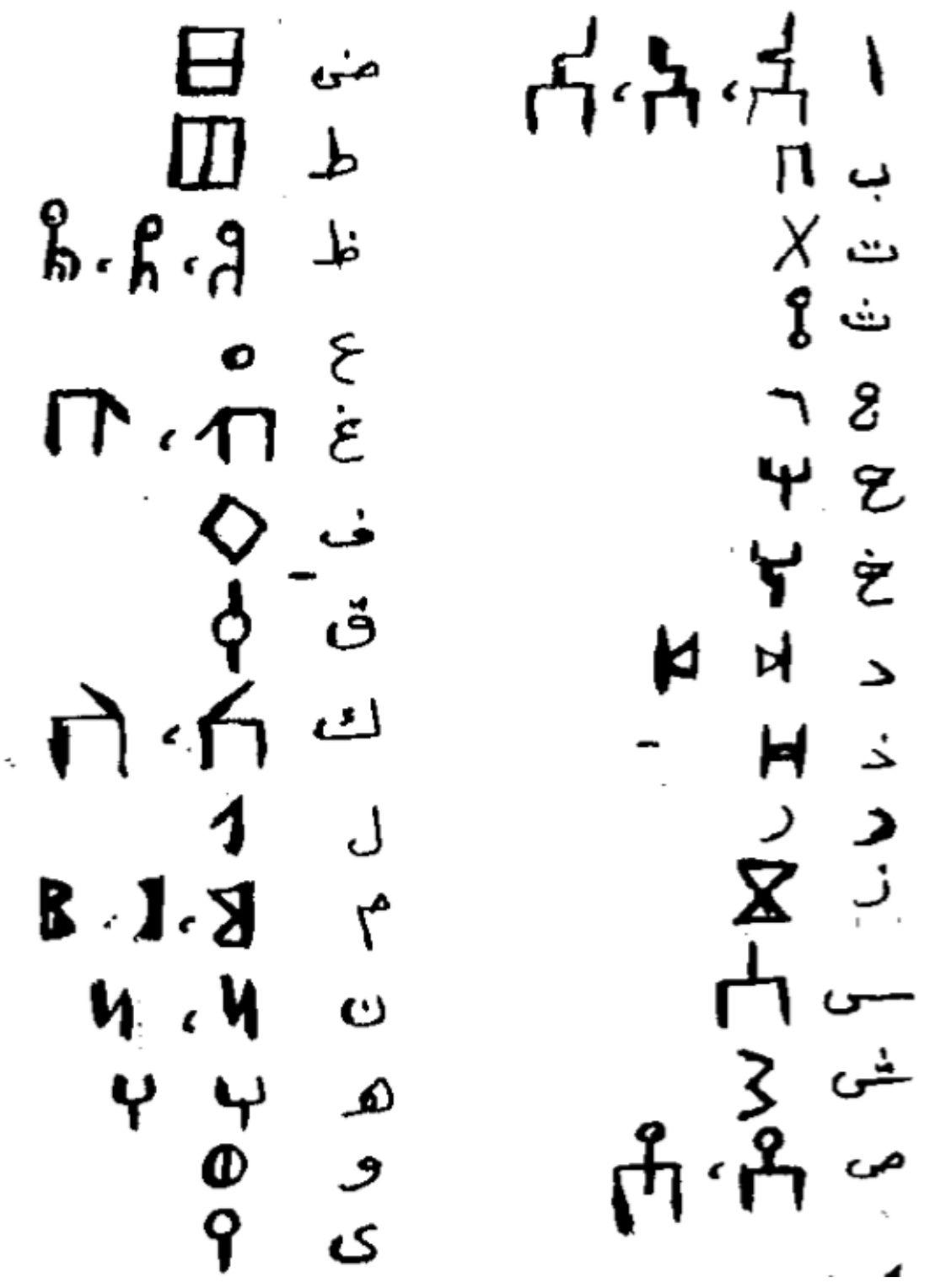

Figure 5. Comparison of Arabic and Musnad scripts

The comparison makes abundantly clear that this theory can neither be totally accepted nor totally refuted because of commonalities between the two styles of calligraphy. The first of these shared traits is that Arabic calligraphy is written right to left, as is the case with individual/odd lines of Musnad calligraphy. In addition, the Arabic alphabet has twenty-eight letters and the Musnad twenty-nine. Of course, there is the addition of the three letters that resemble one another, as indicated above. The influence of Musnad calligraphy on Arabic calligraphy is likely, due mainly to the dissemination of the cultural influence of the Kingdom of Saba on the Arabian 


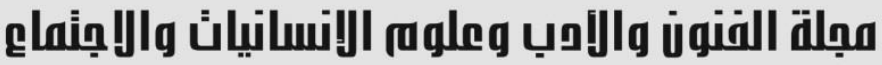 \\ Journal of Arts, Literature, Humanities and Social Sciences www.jalhss.com \\ Volume (54) July 2020 \\ العدد (54) يوليو 2020}

peninsula. The extent of the influence of Musnad calligraphy is a question that remains unanswered, especially if another equally important and unanswered question is considered, a question which could help determine the influence of Sabaean writing on the civilizations that inherited its lands: Did the Kingdom of Saba rely on the oral transmission of its cultural heritage or did it have a written record? In summary, Musnad calligraphy did not have a strong or long-lasting influence over the civilizations that followed. The proof of this is that the influence of Musnad calligraphy was not comprehensive and did not last long in comparison with other cultures investigated in this study.

\section{The Nabataean Theory}

This theory states that the origin of Arabic calligraphy is Nabataean calligraphy. This theory has been adopted by many specialists, especially in the modern era because of the discovery of inscriptions and monuments that support it. Rahim (2009) references the strong resemblance of Nabataean to Arabic calligraphy as proof of the theory.

The Nabataeans were an Arab people who settled in the area stretching from Euphrates River to Sinai, with Madain Saleh, in the northwestern region of the Arabian peninsula, as their first homeland; Petra, in northern region of the Arabian peninsula was their capital (Ibrahim, 2014). Madain Saleh was an essential center along the trade route that stretched from Hejaz to the northern part of the Arabian peninsula.

Nabataean writing appears in the central and western regions of the Arabian peninsula in the second century A.D. Specialists state that Nabataean calligraphy, derived from Aramaic calligraphy, evolved rapidly and transformed into Arabic calligraphy between 300 and 400 A.D. It emerged plainly during the pre-Islamic era as the calligraphy used in Hejaz and Sham at the start of the fourth century A.D. Archaeological evidence demonstrates that Arabic uses Nabataean letters (Fig. 6). The Namara inscription from the grave of the renown Arabian king Imru' al-Qais dates to 328 A.D. (Mousa, 2001). 


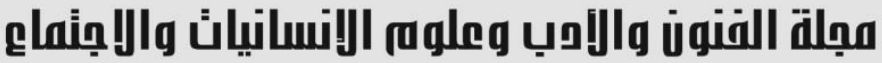

Journal of Arts, Literature, Humanities and Social Sciences www.jalhss.com

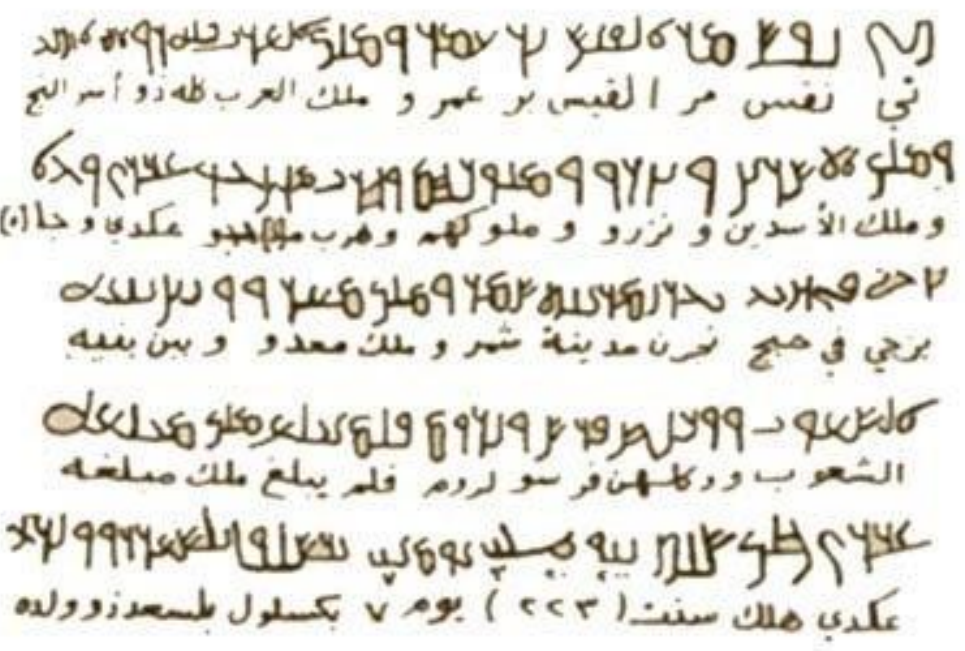

Figure 6. Namara inscription

In addition, other inscriptions of Nabataean calligraphy are in a language that closely resembles the form of the Arabic language through which the Holy Quran was revealed (Abulhab, 2007). These inscriptions resemble Arabic script, especially the Koufi script-like Zaid inscription that dates to 512 A.D. (Fig. 7) and the Harran inscription (Fig. 8), which dates to 568 A.D. These inscriptions confirm the connection between Arabic and Nabataean calligraphy.

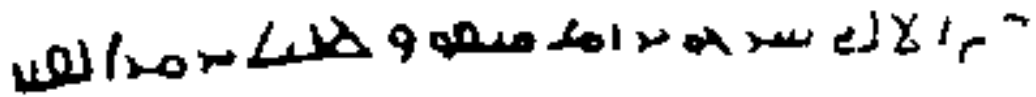

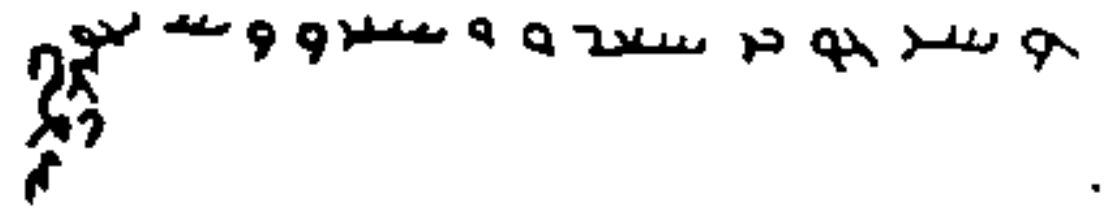

Figure 7. Zaid inscription 


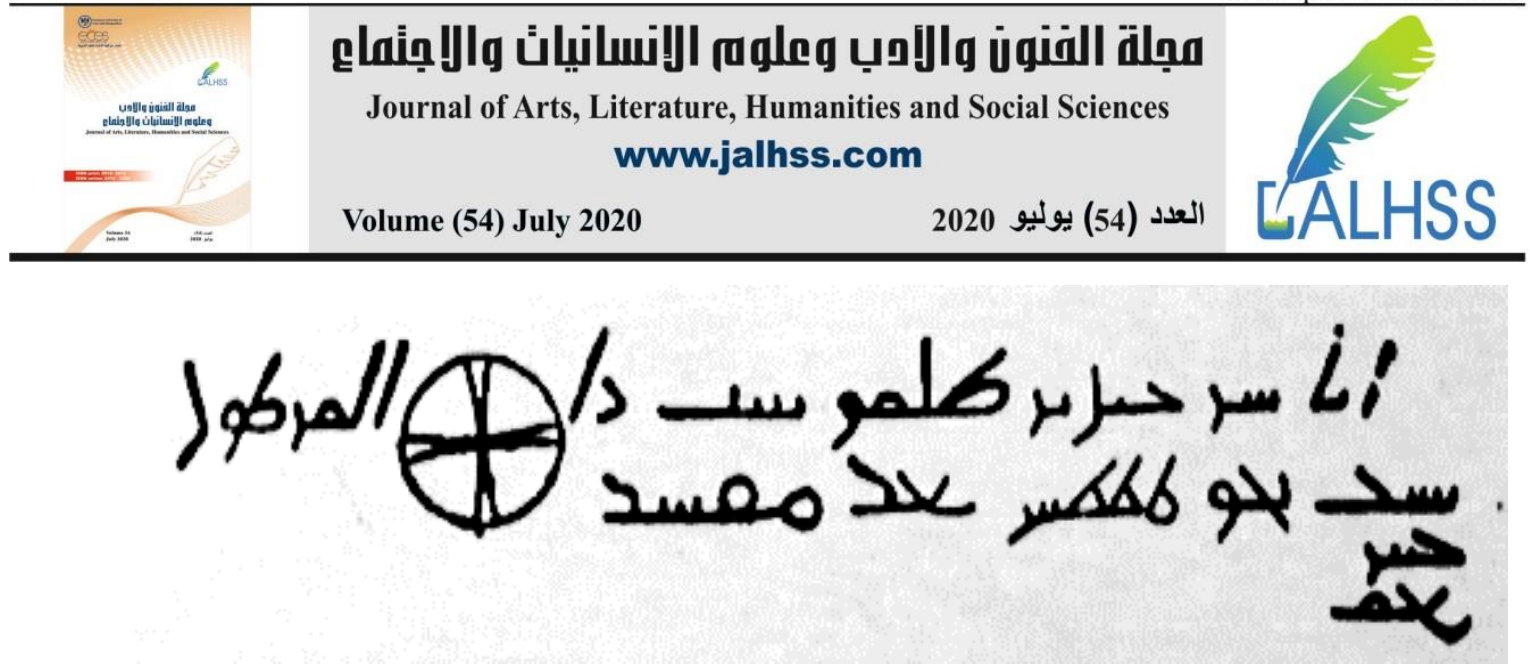

Figure 8. Harran inscription

The author recognizes the noteworthiness of this theory; it is based on several important claims:

1) There is concrete evidence, such as inscriptions and other artifacts, that confirms the close convergence of Arabic and Nabataean calligraphy.

2) Both ancient Arabic and Nabataean calligraphy are written without dots.

3) Both scripts are written right to left.

4) Both the appearance and shape of Arabic and Nabataean letters change according to their placement within words.

5) Both Arabic and Nabataean abide by similar rules concerning linguistic principles and structures.

6) Specialists have confirmed that the Nabataeans were using a form of Arabic, which was close to the language of Hejaz (Mousa, 2001). Ninety percent of the nouns they used were Arabic.

Taken together, these proofs support the author's stance that Nabataean calligraphy is the most logical and appropriate precursor to modern Arabic calligraphy. In addition, these findings also support the author's assertion that Musnad calligraphy has a limited influence on Arabic calligraphy.

Indeed, a precise analysis of Arabic and Nabataean calligraphy confirms that there is a strong resemblance on three important levels: the shape of the letters, the formation of words, and writing style. The three aspects of resemblance constitute the strongest support for the theory.

Arabic calligraphy has undoubtedly been influenced by the many other languages and calligraphic styles (such as Persian) adopted by neighboring civilizations on the Arabian peninsula. Musnad calligraphy had a clear influence on modern Arabic calligraphy, as has been demonstrated above. However, the connection between Arabic and Nabataean calligraphy is different; Nabataean calligraphy constitutes an important source for modern Arabic calligraphy, which is itself a sophisticated extension of Nabataean calligraphy.

One factor that contributed to Nabataean calligraphy being the main source for Arabic calligraphy is its temporal proximity to the appearance of Islam. Islam 


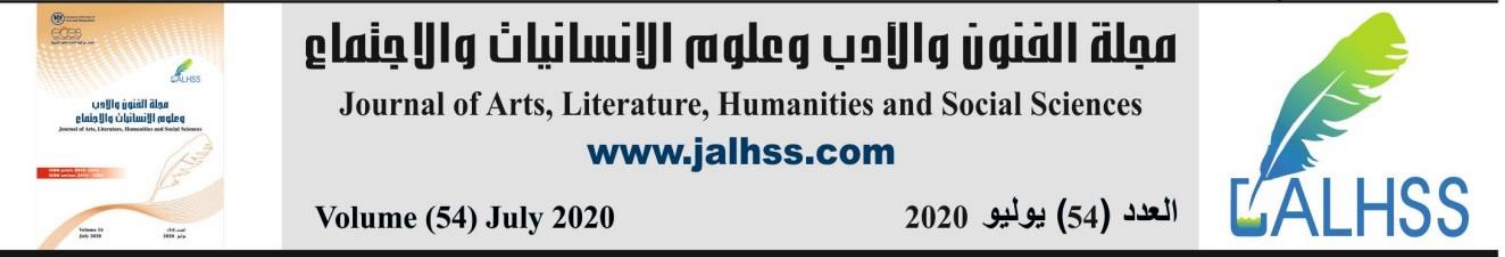

adopted the calligraphic style of Arabic writing derived from the Nabataean, which was not widely used on the Arabian peninsula before 622 A.D. Before this time, Arabs were not much concerned with calligraphy for several reasons, but particularly because it was an oral culture. Arabic culture depended mainly on poems and rhetorical speeches to record their lives and history. In addition, the structured teaching of reading and writing was lacking and their nomadic lifestyle was unstable.

The most recent archeological discovery made in Saudi Arabia was an archeological inscription found in a deserted area of Wadi Tharouq, in Daws in Al-Mandaq Province, located in the Al-Baha region in the southwestern part of the country. Announced on July 29, 2019, by Riyadh Newspaper and the Saudi Commission for Tourism and National Heritage, this stone inscription dates back to the seventh century AD. It is a passage from the Quran that includes the name of the person who made the inscription, Muhammad Ibn Abd Allah (Zahrani, 2019).

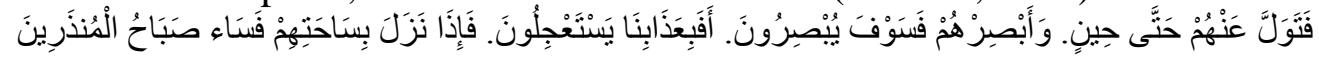

[So, leave them for a time. And see what will befall them, for they are going to see. Then for Our punishment are they impatient? But when it descends in their territory, then evil is the morning of those who were warned.] (Kor 37, 174-177)

Analysis reveals the similarity between the script of this inscription and Nabatean calligraphy in terms of the composition of the words and the character forms that are completely devoid of points (Figure 9).

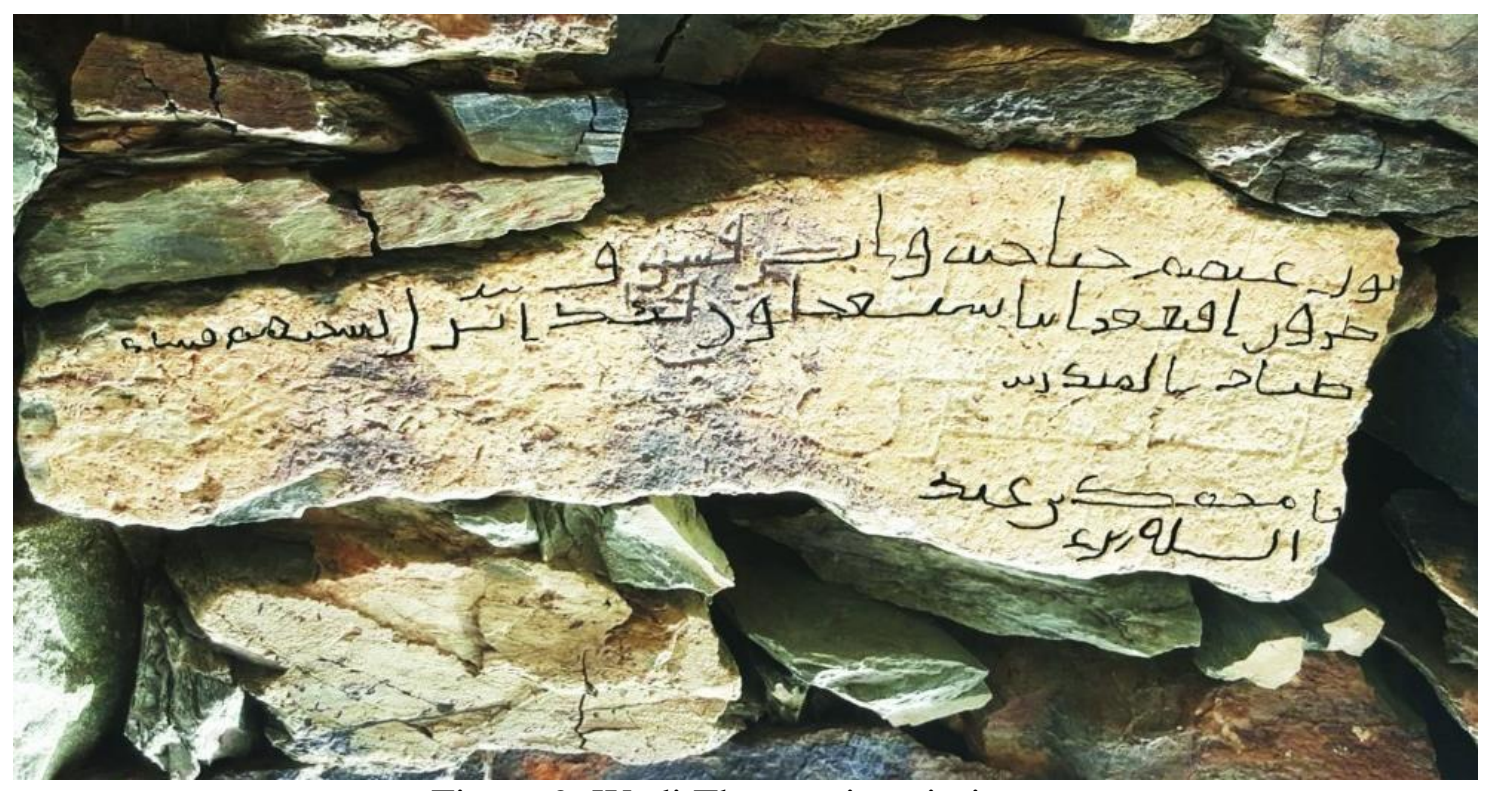

Figure 9. Wadi Tharouq inscription

The similarity is particularly evident in the word حتا, which is not written like modern Arabic حتى. The word المنذرين shows a Nabataean influence. 


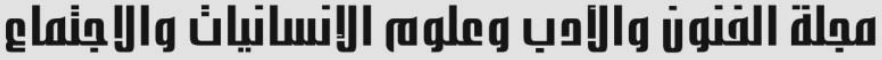 \\ Journal of Arts, Literature, Humanities and Social Sciences www.jalhss.com \\ Volume (54) July 2020 \\ العدد (54) يوليو 2020}

The inscription can be classified as Kufi style calligraphy, which originated in Anbar where Nabataean calligraphy was used. This inscription closely resembles in its composition and form the Harran inscription, mentioned above, though the two texts have no words in common.

This modern discovery also confirms that Arabic calligraphy was influenced by Musnad calligraphy in two aspects. First, some of the letters in this inscription are identical to Musnad style. Where it is possible to observe how the words يبصرون and are written, some of the letters are similar to the Musnad style. The second aspect is that the structure and general shape of this inscription resemble Musnad style, with the presence of many sharp angles in both styles of calligraphy. This is what persuades the author of the correctness of what might be called a "compromise theory", which gives the origin of Arabic calligraphy as an amalgam of Nabatean and Musnad styles.

This discovery was made by a journalist at Riyadh Newspaper, which named the inscription "Wadi Tharouq". The discovery was registered in coordination with the Saudi Commission for Tourism and National Heritage.

Based on the above presentation of theories of the origin of Arabic calligraphy, the reasons for the differences of opinion should be clear. One reason for this difference is that Arabic culture, in both its writing and calligraphy, was influenced by many neighboring civilizations dominant during different periods of time, including Persia, Rome, African peoples that migrated across the Strait of Bab-el-Mandeb, Yemen, and the ancient civilizations that arose on the Arabian peninsula. Still, the main reason for the disparity, in the author's opinion, is the lack of interest in archaeological research on the Arabian peninsula, which is still feeble and obsolete. Archaeological surveys and discoveries can provide concrete evidence, which can be analyzed to reach scientific conclusions. In fact, with a larger number and greater variety of archaeological discoveries concerning the origin of Arabic calligraphy, claims to the truth could be minimized based on the provision of evidence.

Interestingly, the first archaeological discoveries, and the start of modern exploration on the Arabian peninsula, came by chance. The Saudi Arabian oil company Aramco was conducting exploratory drilling in the middle of the desert in the Kingdom of Saudi Arabia in 1952. At that time, signs of the existence of previous civilizations, which had been buried under the sand, appeared. The location was recorded and a landmark established, but exploration did not commence for twenty years, 1 when an expedition from the University of King Saud began excavation in 1972. The expedition excavated Alfaw village, the capital of the Kingdom of Kindah, which dates back to $500 \mathrm{BC}$ This discovery unearthed a kingdom buried under the sand along with all its precious artifacts. 


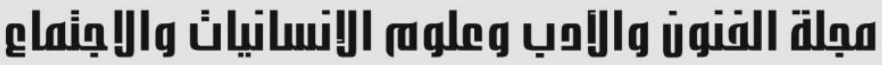 \\ Journal of Arts, Literature, Humanities and Social Sciences www.jalhss.com}

Volume (54) July 2020

العدد (54) يوليو 2020

Basic archaeological research also discovered the village of Al-Rabatha, established in $651 \mathrm{BC}$ near Hejaz, along the pilgrims' route from Iraq to Mecca. This village was discovered by a team of scientists from the University of King Saud in 1980. The discovery contains important artifacts, including Arabic writings and inscriptions that date to the beginning of Islam.

Indeed, these discoveries enhance those scientific theories that rely on concrete evidence and which can be relied upon to determine the origin of Arabic calligraphy. However, in the absence of archaeological discoveries, theories remain mere opinions that can only be either believed or dismissed.

\section{Conclusion}

Determining one specific source of contemporary Arabic calligraphy is not as easy as it may seem. This is because the Arabian Peninsula is surrounded by many civilizations who have mutually influenced one another. Therefore, it is not odd that Arabic calligraphy is a mixture of many ancient influences. In addition, the adoption of Arabic calligraphy by Islam in the writing of the Quran drove the evolution of the art, as calligraphers competed to present it in the best image possible and made calligraphy one of the most significant of the Islamic arts.

Through the examination of the major theories of the origin of Arabic calligraphy and a comparison of the evidence these theories rely on, the author concludes that Arabic calligraphy has been influenced by the calligraphy of many cultures. However, what scant evidence is available in terms of inscriptions and ancient writings demonstrates that Arabic calligraphy is a development of Nabataean calligraphy, from the northern region of the Arabian peninsula, that encountered Musnad calligraphy from the south. These two scripts met in Hejaz and gave birth to Arabic calligraphy. The major components come from Nabataean calligraphy with the Musnad script having contributed some letters. The discovery of the Wadi Tharouq provides evidence for a "compromise theory". The inscription shows characteristics of Nabataean calligraphy influenced by the Musnad style, supporting the claim that the origin of Arabic calligraphy is an amalgam of Nabatean and Musnad styles of calligraphy.

This study makes clear that there are many opinions regarding the origin of Arabic calligraphy, which leads logically to the emergence of many different theories, each claiming to be the true account. This demonstrates the necessity of further effort and systematic scientific research through the analysis of existing artifacts as well as those that remain to be discovered in the future. In addition, a great deal of effort is needed from the relevant official bodies for the exploration and excavation of these yet-to-be-discovered artifacts. 


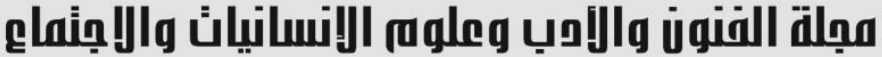

Journal of Arts, Literature, Humanities and Social Sciences www.jalhss.com

Volume (54) July 2020

العدد (54) يوليو 2020

\section{References}

1. Abulhab, S. (2007). Roots of Modern Arabic Script: From Musnad to Jazm. City University of New York Research, 21, 50-71.

2. Alansari, A. (1982). Qaryat al-Faw: A Portrait of Pre-Islamic Civilisation in Saudi Arabia. Riyadh: King Saud University publications. p. 146.

3. Allen, R. (2000). The Arabic Language in Theory and Practice. Middle East Studies Association Bulletin, 34(2), 197-199. Retrieved from http://www.jstor.org/stable/23064130.

4. Baglawa, Mhmed. (2016). Dilmon Civilization Rises and Shines Again. Journal of Popular Heritage. 21 (1), 33 - 51.

5. Baluch, Bahman. (2006). Persian Orthography and Its Relation to Literacy," in Handbook of Orthography and Literacy, ed. R. Malatesha Joshi and P.G. Aaron. London: Lawrence Erlbaum Associates, 365-76.

6. Bishop, Brian. (1998). A History of the Arabic Language. Linguistics Journal. 450. 9-19.

7. Deborah, M. (2013). The Queen of Shebai Legend, Literature and Lore. McFarland and Company Inc Publishing. North Carolina. 142.

8. Diamond, Jared. (3005). Guns, germs and steel. The story of writing. Lion Television. Retrieved from www.pbs.org/gunsgermssteel/variables/writing.html.

9. Ibrahim, Ali. (2014). Origins of Arabic writing. Arabic Language Forum. Riyadh. 18/3/2014.

10. Lafi, Badria. (2015). The Impact of Persian Science on the Sciences of the Arabs from the Islamic Conquest to the End of the Abbasid Era. Master's Thesis. Um Alqura University. 287-289.

11. Mahdi, Salih. (2014). Opinions and Theories on the Origin of Writing. Wasit Journal for Humanities. 12, 89-111.

12. Mousa, I. (2001). The Arabs in the First Communication Revolution: The Development of the Arabic Script. Canadian Journal of Communication, 26(4), 245-261.

13. Omran, Hamdi. (2009). Arabic Writing. Arts College. South of Wadi University. Modern Academy for university books. 82 - 87.

14. Rabi, M., Amrouch M., and Mahani, Z. (2018) Hybrid HMM/MLP Models for Recognizing Unconstrained Cursive Arabic Handwritten Text. In: Ezziyyani M., Bahaj M., Khoukhi F. Advanced Information Technology, Services and Systems. Lecture Notes in Networks and Systems, Springer 25. 115-132.

15. Rahim, Hashim. (2009). Nabatian Theory on the Origins of Modern Arabic Calligraphy. Wasit Journal for Humanities. 5 (10), 139-152

16. Raina, N. \& Alotaibi, N. (2018). The History and Development of Arabic Calligraphy. International Journal of Research and Innovation in Social Science. 2(6). 33-51. 


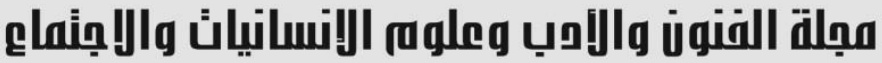

Journal of Arts, Literature, Humanities and Social Sciences

www.jalhss.com

17. Razzak, M.I. \& Mirza, Ali. (2011). Ghost Character Recognition Theory and Arabic Script Based Languages Character Recognition. Przeglad Elektrotechniczny. 87. 234-238.

18. Showman, Ahmed. (2001). The Journey of Arabic Calligraphy. Damascus: Arabs writers union. 19 - 28.

19. The Noble Quran, Translated by Mohammad Alhilali (Madinah: king Fahad complex for the printing of the Holy Quran, 2013).

20. Zahrani, Ibrahim. (2019). Again, Riyadh Investigated an Important Archaeological Inscription in Albaha. Riyadh Newspaper, July 29, 2019, 3224. p. 17. 